\title{
Influence of Board Density on the Physical and Mechanical Properties of Bamboo Oriented Strand Lumber
}

\author{
Yuhui Sun ${ }^{1,2}$, Yahui Zhang ${ }^{1}$, Yuxiang Huang ${ }^{1}{ }^{\mathbb{D}}$, Xiaoxin Wei ${ }^{2}$ and Wenji Yu ${ }^{1, *}$ \\ 1 Key Laboratory of Wood Science and Technology of State Forestry Administration, Research Institute of \\ Wood Industry, Chinese Academy of Forestry, Beijing 100091, China; sunyuhui198507@163.com (Y.S.); \\ zhangyh0206@163.com (Y.Z.); yxhuang@caf.ac.cn (Y.H.) \\ 2 Shandong Xingang Enterprise Group Limited Company, Linyi 276000, China; xgityf@163.com \\ * Correspondence: chinayuwj@126.com
}

Received: 10 April 2020; Accepted: 11 May 2020; Published: 18 May 2020

\begin{abstract}
The process of bamboo-oriented strand lumber (BOSL) represents one of the best opportunities for automation, property control and consistency, and high utilization of material from abundant, fast-growing, and sustainable bamboo. In this study, BOSLs were prepared, with reference to the preparation process of bamboo scrimber, by compressing and densifying constituent units under the action of moisture-heat-force and resin polymerization, and then the effects of density variation on their physical and mechanical properties were investigated. The results revealed that the modulus of rupture, modulus of elasticity, compressive strength and shear strength of BOSL with density of $0.78-1.3 \mathrm{~g} / \mathrm{cm}^{3}$ ranged from 124.42 to $163.2 \mathrm{MPa}, 15,455$ to $21,849 \mathrm{MPa}, 65.02$ to $111.63 \mathrm{MPa}$, and 9.88 to $18.35 \mathrm{MPa}$, respectively. The preparation of BOSL with bamboo as raw material could retain the good mechanical properties of natural bamboo, and produce bamboo-based structural products with different properties by controlling the density. The high strength of BOSL with high density was primarily due to the increased volume fraction of elementary fibers, the reduced porosity, and the enhanced gluing interface. The performance of BOSL can be comparable to, or surpass that of, wood or bamboo products. This study provided necessary basic research for the engineering design and application of BOSL.
\end{abstract}

Keywords: bamboo-oriented strand lumber; density; physical and mechanical properties; microscale morphology

\section{Introduction}

With the contradiction between forest protection and lumber demand becoming increasingly prominent, structural timbers imported from foreign markets have been mainly used to meet China's wood demand. However, Bamboo is widely available in China, and due to its short growth cycle and high strength, it is a promising material to became a substitute for imported wood [1,2]. It was reported that the mechanical properties of bamboo were comparative to North American wood commonly used for structural purposes, such as eastern White pine, Douglas fir and White spruce [3]. Due to the hollow structure and small section size of bamboo, studies varied from the use of full culm bamboo to bamboo-based structural products. The effective utilization of bamboo as raw material for structural products has been substantially studied, for instance, bamboo scrimber [4,5], laminated bamboo lumber (LBL) [6], bamboo plywood [7,8], and bamboo-oriented strand board $[9,10]$. The results showed that these bamboo products had excellent performance, and could be used as light structural members, such as sheathing, studs, columns and beams, and members of heavy load structures and weather durable materials. 
At present, bamboo scrimber, LBL and bamboo plywood have been widely used at home and abroad. However, bamboo scrimber and bamboo plywood have a low degree of automation in processing, and LBL suffers from low material utilization [11,12]. BOSL is defined as a composite of strand elements with bamboo fibers oriented primarily along the length of the member, and BOSL is an extension of the technology used to produce oriented strand boards (OSB) as structural panels [13]. The production process of BOSL, similar to that of OSB, has the advantages of high bamboo utilization, high degree of automation, small performance difference compared to sawn timber, and mass production [14-17]. Because of the high longitudinal strength of bamboo fibers, BOSL can also provide the most efficient section to resist axial forces and flexural loads parallel to oriented fibers [18]. The research on BOSL is still in the laboratory stage. Malanit et al. [19] concluded that the adhesive type and amount had significant influence on the performance of BOSL, and BOSL had better water resistance than pine-based oriented strand lumber (OSL). Sumardi et al. [20] found that the change of board type and strand length had a great effect on the flexural properties and internal bond strength of BOSL. Semple et al. [21] concluded that OSL prepared by mixing wood and bamboo strands had better water resistance than that prepared by wood strands alone. These studies also showed that the density and mechanical properties of BOSL were generally close to those of wood-based OSL, and BOSL had no obvious advantage of properties. In order to make full use of the high strength, and overcome the disadvantage of high density, of bamboo [22], further study is needed to improve the performance of BOSL and increase its product added value. According to the performance requirements of target products in different fields, designing BOSL with different properties would be an efficient approach to expanding the BOSL application field.

In this study, the effects of density on the physical and mechanical properties of the BOSL were investigated. Furthermore, the microscale morphology of samples with different densities was observed by ultra-depth electron microscopy and scanning electron microscope (SEM). The internal porosity and pore diameter distribution of the samples with different densities were calculated by mercury intrusion porosimetry. The aim of this study was to provide a theoretical basis and technical support for promoting the design, application and popularization of BOSL in different fields.

\section{Materials and Methods}

\subsection{Materials}

In this study, 4 to 6 year-old bamboo (Dendrocalamus giganteus Munro) culms from Mangshi, Yunnan, China, were chosen as the experimental material. The average diameter at breast height was $15.7 \mathrm{~cm}$, with an average culm wall thickness of $13 \mathrm{~mm}$ at this height. Phenol formaldehyde (PF) resin (Beijing Dynea chemical industry Co., Ltd., Beijing, China) was used as the adhesive. Its viscosity $\left(30{ }^{\circ} \mathrm{C}\right)$ was $40.5 \mathrm{cps}$. The solid content $\left(2 \mathrm{~h} / 120^{\circ} \mathrm{C}\right)$ was $48.06 \%$, and $\mathrm{pH}$ value $\left(25^{\circ} \mathrm{C}\right)$ was $10-11$.

\subsection{Experimental Design and Preparation of BOSL}

Board density was chosen as the control factor. BOSL with target densities of 0.7, 0.8, 0.9, 1.0, 1.1 and $1.2 \mathrm{~g} / \mathrm{cm}^{3}$ were prepared respectively, with three repetitions. Figure 1 shows the fabrication process of BOSL. The culms were first crosscut into 140 150 mm long segments, and then cut into thin pieces in radial direction using a strand disc-flaker. The length, width and thickness of strands were 140 to $150 \mathrm{~mm}$ (longitudinal), 5 to $60 \mathrm{~mm}$ (tangential), and $0.8 \mathrm{~mm}$ (radial), respectively, and the moisture content of dried strands was $5 \%$. The bamboo strands without node were then infused into the adjusted PF resin solution for $5 \mathrm{~min}$ at general temperature. Afterwards, the excessive resin on strands percolated up, and the strands were weighed to attain the resin loading of $15 \%$ based on oven-dry strand mass. The impregnated bamboo strands were dried at $60{ }^{\circ} \mathrm{C}$ to reach a moisture content of $12 \%$. The BOSL layers were formed by hand, with bamboo fibers primarily oriented along the length of member in a compression mold. The board was hot pressed at $150{ }^{\circ} \mathrm{C}$ for 15 min under a pressure of 4-7 MPa, depending on the density of board. The BOSLs were produced with a dimension 
of $300 \mathrm{~mm}$ (length) $\times 100 \mathrm{~mm}$ (width) $\times 15 \mathrm{~mm}$ (thickness). After that, the boards were placed in a conditioned room at $25-30{ }^{\circ} \mathrm{C}$ and $60-65 \%$ relative humidity for 14 days, until constant weight was attained. The final moisture content of specimen was about $5 \%$.

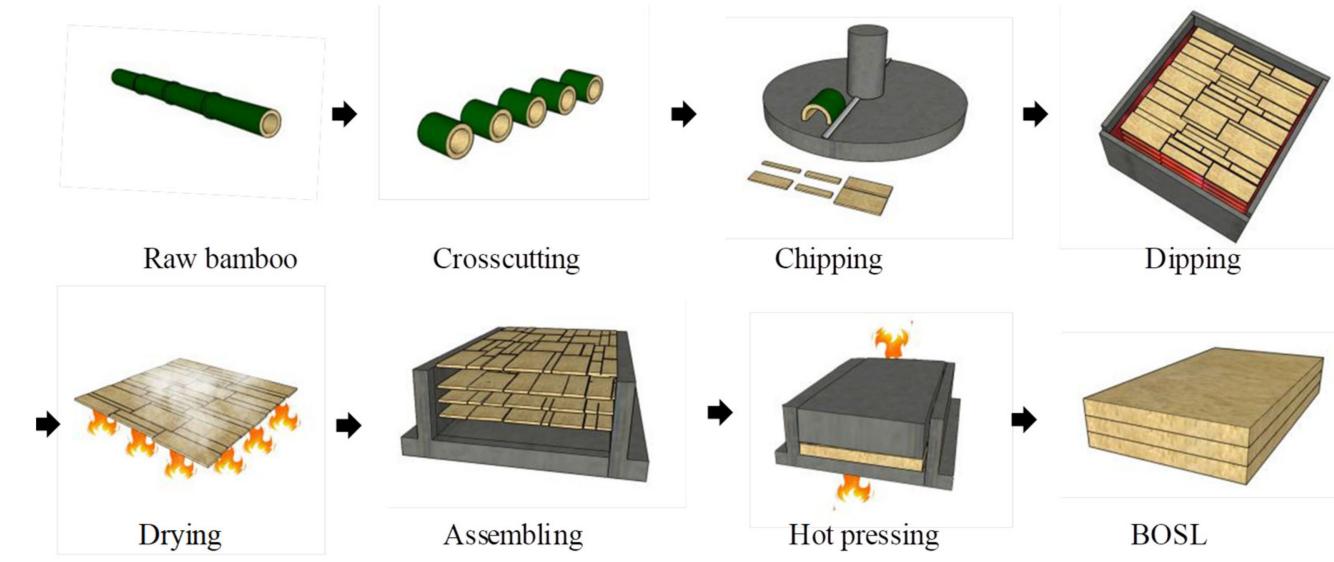

Figure 1. Diagrams of BOSL preparation.

\subsection{Physical and Mechanical Properties Test}

The lab boards with stable moisture content were machined into test specimens. The physical and mechanical properties were tested as follows (Figure 2), and there were 6 replicate samples in each test.

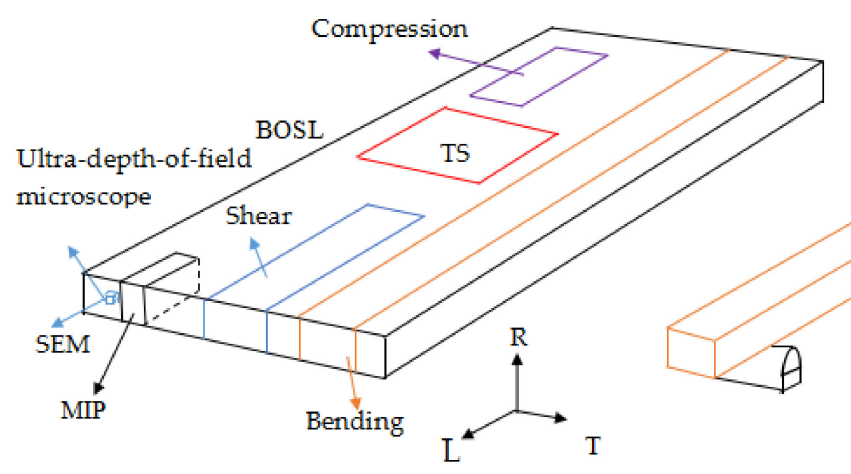

(a)

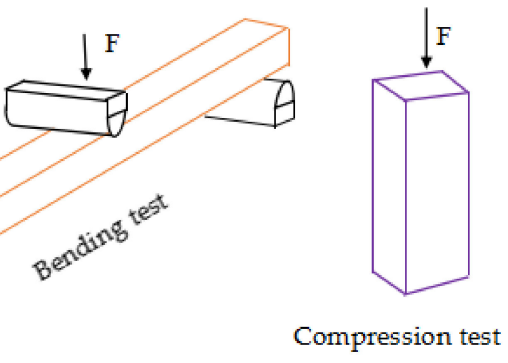

(c)

Figure 2. Details about sampling diagram (a) and testing setup (b,c).

According to ASTM D1037-2012, the actual air-dried density and thickness swelling (TS) were tested, and the dimensions of specimens were $50 \mathrm{~mm}$ length (along the length of board, $\mathrm{L}$ ), $50 \mathrm{~mm}$ width (T), and $15 \mathrm{~mm}$ thickness (R). The TS specimens were fully impregnated in water at $63^{\circ} \mathrm{C}$ for $24 \mathrm{~h}$, and TS was then calculated based on thickness measured at the very center of the specimen.

The modulus of rupture (MOR) and modulus of elasticity (MOE) of BOSLs were evaluated using three-point bending test (Figure 2b) according to GB17657-2013 standard. The samples with a dimension of $300 \mathrm{~mm}(\mathrm{~L}) \times 20 \mathrm{~mm}(\mathrm{~T}) \times 15 \mathrm{~mm}(\mathrm{R})$ were tested at a constant crosshead speed $(8 \mathrm{~mm} / \mathrm{min})$ and the span of $260 \mathrm{~mm}$.

Compression tests were performed in the longitudinal directions on cuboid-shaped specimens (Figure 2c), with the dimensions of $60 \mathrm{~mm}(\mathrm{~L}) \times 25 \mathrm{~mm}(\mathrm{~T}) \times 15 \mathrm{~mm}(\mathrm{R})$, according to ASTM D1037-2012 using a crosshead speed of $1 \mathrm{~mm} / \mathrm{min}$.

The short-beam shear test was in accordance with ASTM D2344-2016, using three-point bending test. The specimen machined from BOSLs was a short beam with the dimension of $110 \mathrm{~mm}(\mathrm{~L}) \times$ $20 \mathrm{~mm}(\mathrm{~T}) \times 15 \mathrm{~mm}(\mathrm{R})$. The span was $60 \mathrm{~mm}$, and the constant crosshead speed was $1.0 \mathrm{~mm} / \mathrm{min}$. 


\subsection{Morphological Characterizations}

SEM was used to observe the morphologies of bamboo and BOSL. The specimens of bamboo and BOSL for SEM observation were sliced by Leica RM2245 slide-away slicer, which were extracted from the central part along the thickness direction (Figure 2a). The above specimens were fixed in the sample holder. After coating with gold, and setting to $10 \mathrm{kV}$ operating voltage, the morphologies of bamboo and BOSL were observed by SEM.

\subsection{Interface Observation by Ultra-Depth-Of-Field Microscope}

The specimens were sliced with a Leica RM2245 slicer to obtain a $4 \mathrm{~mm}$ long, $4 \mathrm{~mm}$ wide and $20 \mu \mathrm{m}$ thick transverse section exposing a bondline. The specimen was sampled from the middle of the sample (Figure 2a). For better distinguishing the bamboo matrix and resins, the sections were stained with $0.5 \%$ fluorescent dye toluidine blue solution for 2-3 $\mathrm{min}$, and then the dyed sections were dehydrated with two ethanol solutions: $75 \%$ and $100 \%$. The distribution of PF resin in bamboo tissue was observed using an ultra-depth-of-field microscope.

\subsection{Mercury Intrusion Porosimetry (MIP)}

Micrometrics AutoPore IV 9500 was used in determining porosity and pore distribution of specimen. Firstly, the bamboo and BOSL were cut into $20 \mathrm{~mm}$ long, $15 \mathrm{~mm}$ wide, and measured-thick test specimens, and the specimens were oven-dried at $63^{\circ} \mathrm{C}$ for $48 \mathrm{~h}$. Then the measurements were conducted by incrementing the pressure from $0.0034 \mathrm{MPa}$ to $405.95 \mathrm{MPa}$, to force mercury into the pores of specimens which had been immersed in the mercury. Pore diameter, and cumulative and incremental intruded volume, were recorded for each specimen during total testing. The pore distribution was obtained in accordance with the Washburn equation [23], which illustrates the relationship between pore size and applied pressure.

$$
d=\frac{-4 \gamma \cos \theta}{p}
$$

where $p$ is the applied pressure $(\mathrm{Pa}), d$ is the pore diameter $(\mathrm{m}), \gamma$ is the surface tension of mercury $\left(0.48 \mathrm{~N} / \mathrm{m}\right.$ at $\left.25^{\circ} \mathrm{C}\right)$, and $\theta$ is the contact angle between wood and mercury $\left(141^{\circ}\right)$.

In addition, the MIP method could test the oven-dried bulk density $\rho$ and the specific solid (cell wall) density $\rho_{s}$ of the specimen [24]; the porosity $p$ can be calculated as follows:

$$
P=1-\frac{\rho}{\rho_{s}}
$$

The $\rho$ was defined as the unit weight per unit volume of a material. And $\rho_{s}$ was usually computed after the volume of all pores had been excluded from the volume presumed occupied by the material. The pore volume was determined by the entered pore mercury volume.

\section{Results and Discussions}

\subsection{Effect of Density on Physical Properties of BOSL}

In this study, the target densities of BOSLs were $0.7,0.8,0.9,1.0,1.1$ and $1.2 \mathrm{~g} / \mathrm{cm}^{3}$, respectively, but the corresponding actual measured densities were $0.78,0.92,1.02,1.09,1.22,1.3 \mathrm{~g} / \mathrm{cm}^{3}$ (Figure 3), due to the influence of the preparation process. As seen in Figure 1, TS of BOSL decreases from 10.61\% to $4.39 \%$ with increases in the density from $0.78 \mathrm{~g} / \mathrm{cm}^{3}$ to $1.3 \mathrm{~g} / \mathrm{cm}^{3}$. After $24 \mathrm{~h}$ immersion in water at $63{ }^{\circ} \mathrm{C}$, even BOSL with a density of $0.78 \mathrm{~g} / \mathrm{cm}^{3}$ had low TS-less than $11 \%$. The density of specimens significantly influenced the water-resistance.

As shown in Figure 4a, the porosity of BOSL decreases significantly with the increase of density, and density has a good linear correlation with porosity. Those pores are important openings for water 
impregnation. Thus, the maximum free water content of BOSL decreased with decreases in the porosity, and TS of BOSL had obviously fallen off.

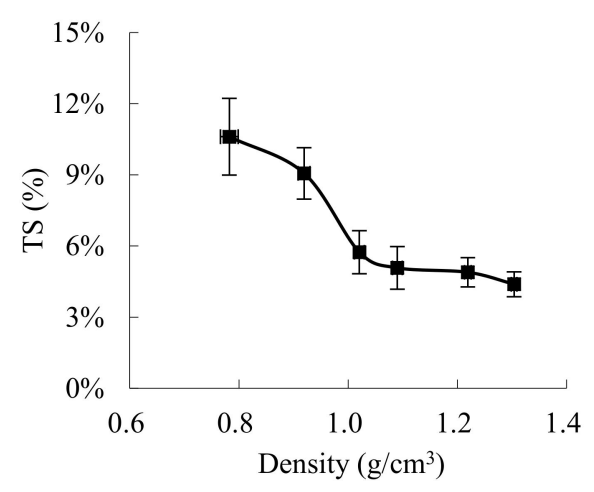

Figure 3. The thickness swelling of BOSL with different densities. The error bars represent standard deviation.

Typical MIP curves for log differential intrusion versus pore diameter, for bamboo and BOSLs, are presented in Figure $4 \mathrm{~b}$. The structure of bamboo is constituted by parenchyma, fibers, and vessel cells. These component cells have a lumen diameter in the range of $21-40 \mu \mathrm{m}[25,26]$ for parenchyma, $0.26-24.96 \mu \mathrm{m}$ for fibers [27,28], and 40.17-259.91 $\mu \mathrm{m}$ for vessels [28], respectively. According to the research of Liu [29], the 10-100 nm pores might be pit membrane voids, pit apertures, and other small voids. Compared to bamboo, BOSLs have different pore diameter distributions (Figure $4 \mathrm{~b}$ ), where the quantity of pores with diameter of 10-100 nm decreased. This might be due to PF resin filling the void space of pits. By comparing the pore size distribution of BOSL (density: $0.78 \mathrm{~g} / \mathrm{cm}^{3}$ ) with that of bamboo, the large size pores of BOSL were significantly more numerous than that of bamboo, which was mainly caused by low compaction ratio and lap joints of strands. With the increase of BOSL density, the quantity of large pores with diameter of above $100 \mathrm{~nm}$ decreased significantly, mainly due to the increase in compression ratio, closer bonding between strands, and compression deformation of parenchyma and vessel cells (Figure 5). These reduced pores of BOSL with high density were difficult to access, and thus pore geometry also affected permeability and water-resistance of BOSL.

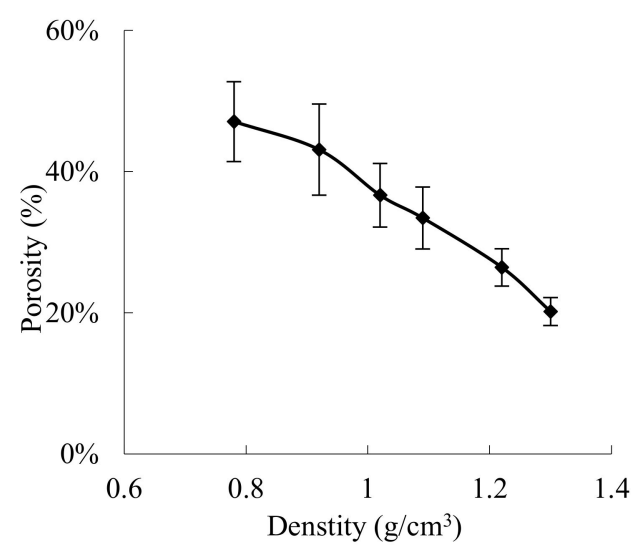

(a)

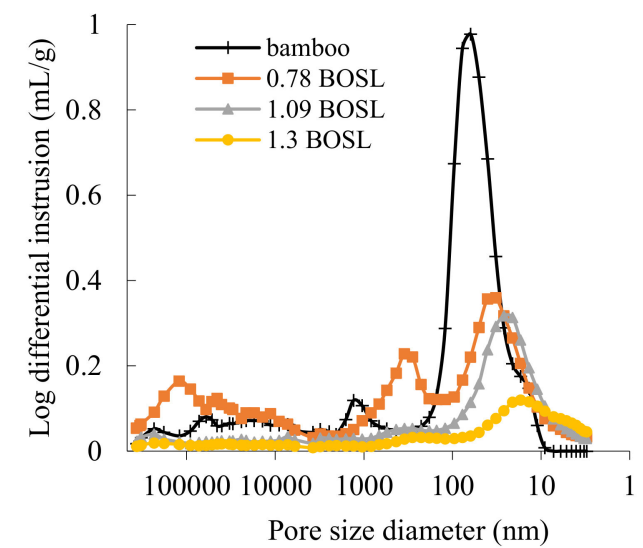

(b)

Figure 4. Correlations between BOSL density and porosity (a), and log differential intrusion versus pore diameter curves for bamboo and BOSL, with various density $(\mathbf{b})$.

Figure 5 shows the photomirographs of stained transverse sections acquired by ultra-depth-of-field microscope. By comparing the bonding interface of BOSL with density of $0.78 \mathrm{~g} / \mathrm{cm}^{3}$ and $1.3 \mathrm{~g} / \mathrm{cm}^{3}$, PF resin has a deeper penetration into parenchyma or fiber cell lumina and cell corners in high-density specimens than in low-density specimens. This is because the strands bonded more closely with 
the increase of density, and the increasing pressure forced resin deeper into the strands. This was consistent with the findings, by Gavrilović-Grmuša et al. [30], that increasing appropriate consolidation pressure led to more resin penetration into wood. It was also proved that penetration had an effect on adhesive bond performance [31]. The greater penetration was associated with more surface contact between adhesive and bamboo substance, thus increasing the potential for secondary bonding forces and covalent bonding. The number of hydroxyl groups on the surface of bamboo cell walls decreased, and the water-adsorption property decreased. Therefore, this will likely be an influential factor in improving the water-resistant performance of BOSL.

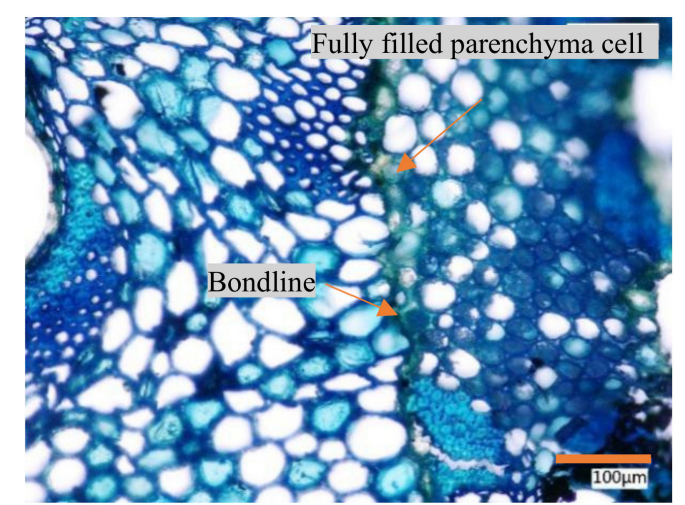

(a)

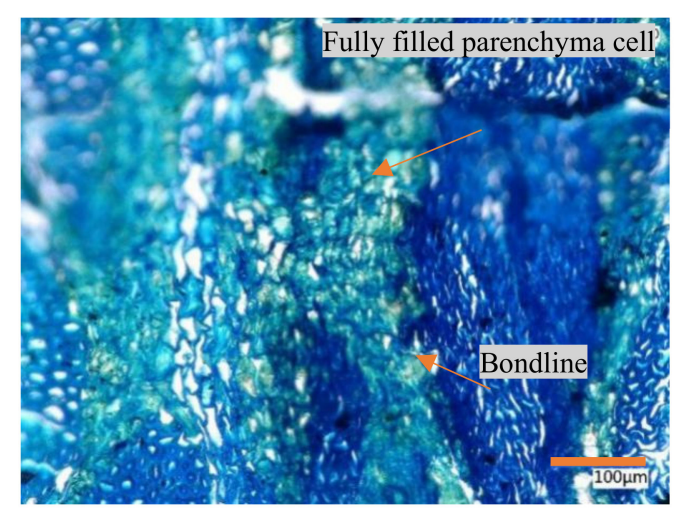

(c)

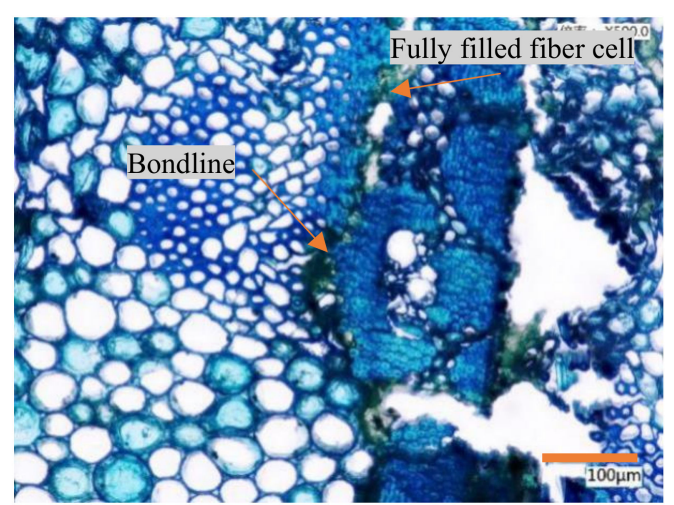

(b)

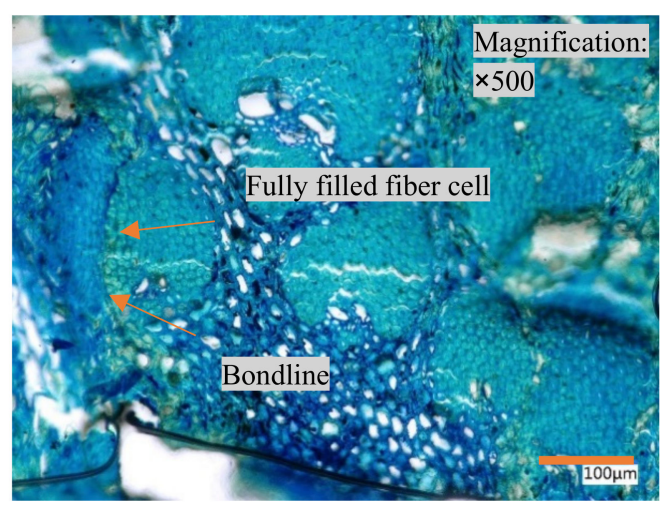

(d)

Figure 5. Ultra-depth-of-field microscope images of PF resin bonding interface of BOSLs with different densities (a,c): $0.78 \mathrm{~g} / \mathrm{cm}^{3}, 1.3 \mathrm{~g} / \mathrm{cm}^{3}$, parenchyma cell bonding; $(\mathbf{b}, \mathbf{d}): 0.78 \mathrm{~g} / \mathrm{cm}^{3}, 1.3 \mathrm{~g} / \mathrm{cm}^{3}$, fiber cell bonding.

\subsection{Effect of Density on Mechanical Properties}

According to Chinese standard GB/T 15780-1995, the air-dry density, MOR, MOE and compressive strength of natural bamboo were measured at $0.72 \mathrm{~g} / \mathrm{cm}^{3}, 148.82 \mathrm{MPa}, 12,130 \mathrm{MPa}$, and $62.16 \mathrm{MPa}$, respectively. As shown in Figure 6, the MOR, MOE and compressive strength of BOSL with density of $0.78 \mathrm{~g} / \mathrm{cm}^{3}$ were found to be similar to that of natural bamboo, but the MOR, MOE and compressive strength of BOSL with density of $1.3 \mathrm{~g} / \mathrm{cm}^{3}$ were $1.09,1.80$, and 1.80 times that of natural bamboo, respectively. This indicated that the preparation of BOSLs with bamboo as raw material could retain the good mechanical properties of bamboo, and produce bamboo-based products with different properties by controlling the density. 


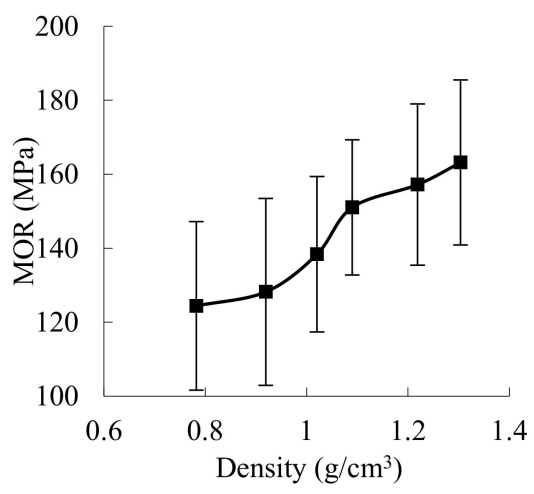

(a)

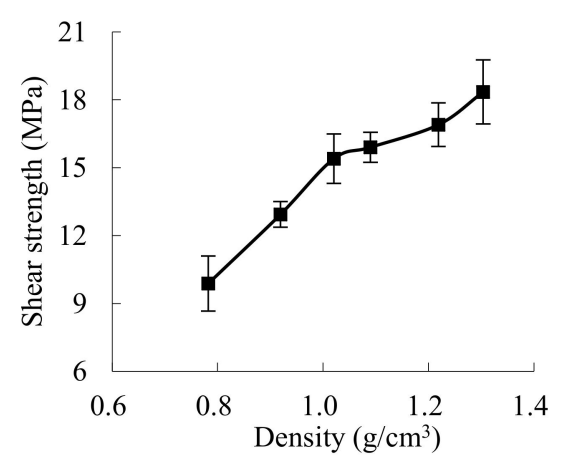

(c)

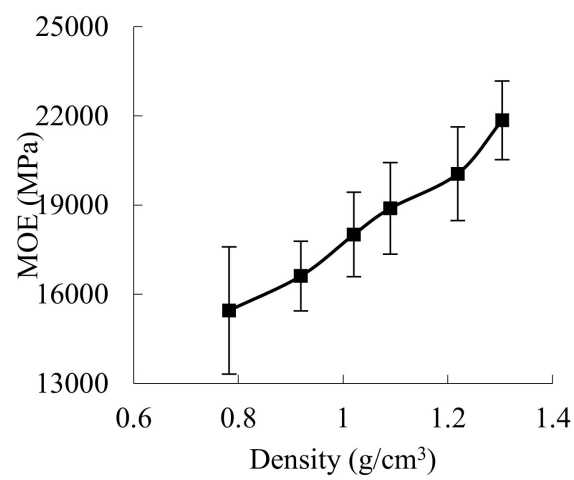

(b)

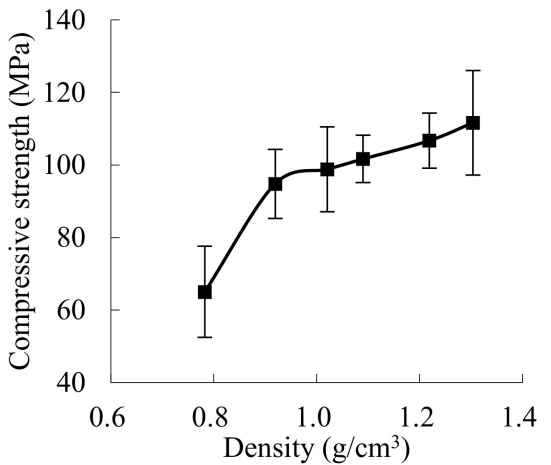

(d)

Figure 6. Density and mechanical relation of BOSL: (a) MOR; (b) MOE; (c) Shear strength; (d) compressive strength.

In this study, the change of density, from $0.78 \mathrm{~g} / \mathrm{cm}^{3}$ to $1.3 \mathrm{~g} / \mathrm{cm}^{3}$, caused the MOR and MOE of BOSL to increase by about $31.17 \%$ and $41.37 \%$, respectively (Figure 4 ). With increases of the density from $0.78 \mathrm{~g} / \mathrm{cm}^{3}$ to $1.09 \mathrm{~g} / \mathrm{cm}^{3}$, the largest MOR increase was reported, increasing to $21 \%$. As the density increased, the rise of MOE varied approximately linearly. The compressive strength and shear strength increased, by $71.69 \%$ and $88.36 \%$, with the increase of density from $0.78 \mathrm{~g} / \mathrm{cm}^{3}$ to $1.3 \mathrm{~g} / \mathrm{cm}^{3}$, respectively. With the increase of density from $0.78 \mathrm{~g} / \mathrm{cm}^{3}$ to $1.09 \mathrm{~g} / \mathrm{cm}^{3}$, the increase of initial shear strength was the largest, and then the increase was slow. The shear strength was associated with bonding properties between layers when the material or component failed in shear. Resin content was also a key factor, causing a change of shear strength, besides the density itself $[13,32]$.

BOSL typically increased in strength with the increase of board density, which was in agreement with the conclusions of Mirski et al. [13] and Yu et al. [32]. The increasing strength of BOSL could be attributed to the reduced porosity and pore geometry. As BOSL was a kind of composite material, the porosity had influences on the distribution forms of stress [33]. Stress concentration occurred near the pores where the fracture initiated. Thus, high-density BOSL with fewer pores was not prone to damage, and showed better strength. Another reason may be the changes in the structure of BOSLs with different densities. As shown in Figure 5a, the bamboo tissue is dominated by vascular bundles embedded in a matrix of parenchyma cells. The vascular bundles were composed of vessels surrounded by fiber cells. After processing bamboo into BOSL with a density of 0.78 $\mathrm{g} / \mathrm{cm}^{3}$, no significant structural changes occurred in parenchyma cells, vessels or fiber cells of bamboo (Figure 7b). Therefore, its strength was close to that of natural bamboo. However, with increases in the density, more parenchyma and vessel cells collapsed (Figure 7c,d) during the mechanical compression, meaning the gluing interface could be enhanced and the hydrogen bonding among the aligned fibers may be formed [1].This resulted in better mechanical properties of BOSL at higher density. In addition, the extruded and deformed parenchyma cells, vessels and parts of fiber cells made the volume fraction 
of elementary fibers increase in BOSL with higher density. The strength of fiber was much greater than that of parenchyma cells [34]. Therefore, the mechanical properties of BOSL were enhanced with the increase of fiber volume fraction. A similar conclusion has been illustrated by $\mathrm{Yu}$ [25], that increasing the volume fraction of fibers enhanced the strength of a bamboo fiber-reinforced composite.
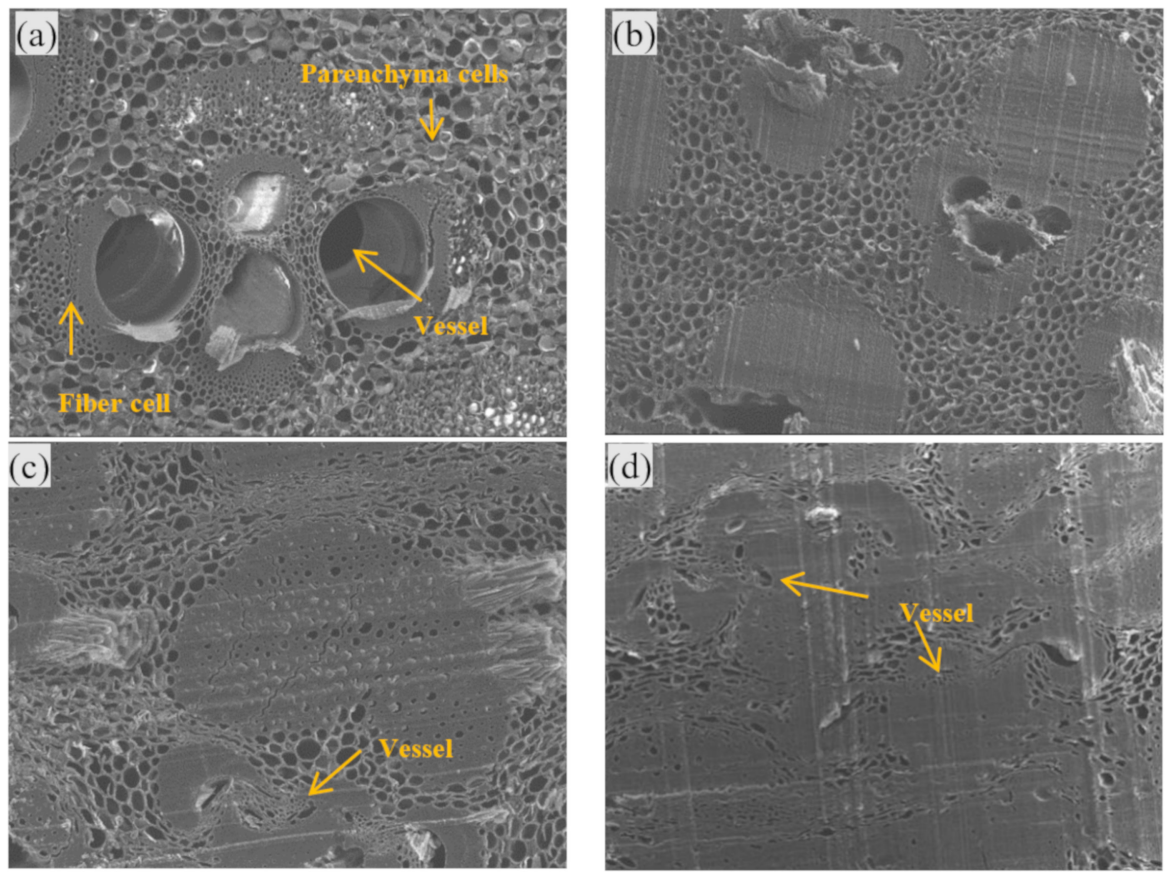

Figure 7. SEM images of bamboo (a) and BOSL with a density of $0.78(\mathbf{b}), 1.09$ (c) and $1.30 \mathrm{~g} / \mathrm{cm}^{3}$ (d). All four images have the same scale bars, $100 \mu \mathrm{m}$, shown in (a).

\subsection{Failure Mode}

There were no obvious differences in failure modes of BOSL with different densities. The failure modes in the bending test were as follows (Figure 8a): The failure occurred at the tension faces of the specimens at mid-span, and the fractured surfaces included abrupt failure and "fibrous" failure, indicating a fracture showing splinters. The breakage of matrix and fiber could cause the flexural failure on the tension surface of specimens. The broken compressive surface could attribute to the buckling of specimens. In addition, longitudinal shear failures were also observed during bending test. Figure $8 \mathrm{~b}$ shows compressive failures of BOSLs. It was generally one, or a combination, of the failure patterns, including shearing, splitting and inelastic buckling, which was possibly attributed to microbuckling surrounded by delamination. A similar failure was noted by Anuj Kumar et al. [35] and Li et al. [36] in the samples (along the longitudinal direction) of bamboo scrimber and wood scrimber. Figure $8 \mathrm{c}$ shows shear failure of BOSLs. The specimen subjected to loading in this test method not only produced the interlaminar shear failure in mid-plane, but also caused inelastic deformation. The severe shear-stress concentration, combined with transverse and in-plane compressive stresses, has been shown to be the cause of initiate failure. Specifically, there was a dense tissue in the outer part of the bamboo culm, so the resin was possibly incapable of deeper penetration. Beyond that, loose and fragile tissue in the inner part of the culm might inhibit surface attachment of the resin to the bamboo cells [20]. The glued joint of strands prepared from these parts was a weak spot, where severe stress concentration would probably appear, and this may be the cause of initiate failure. 


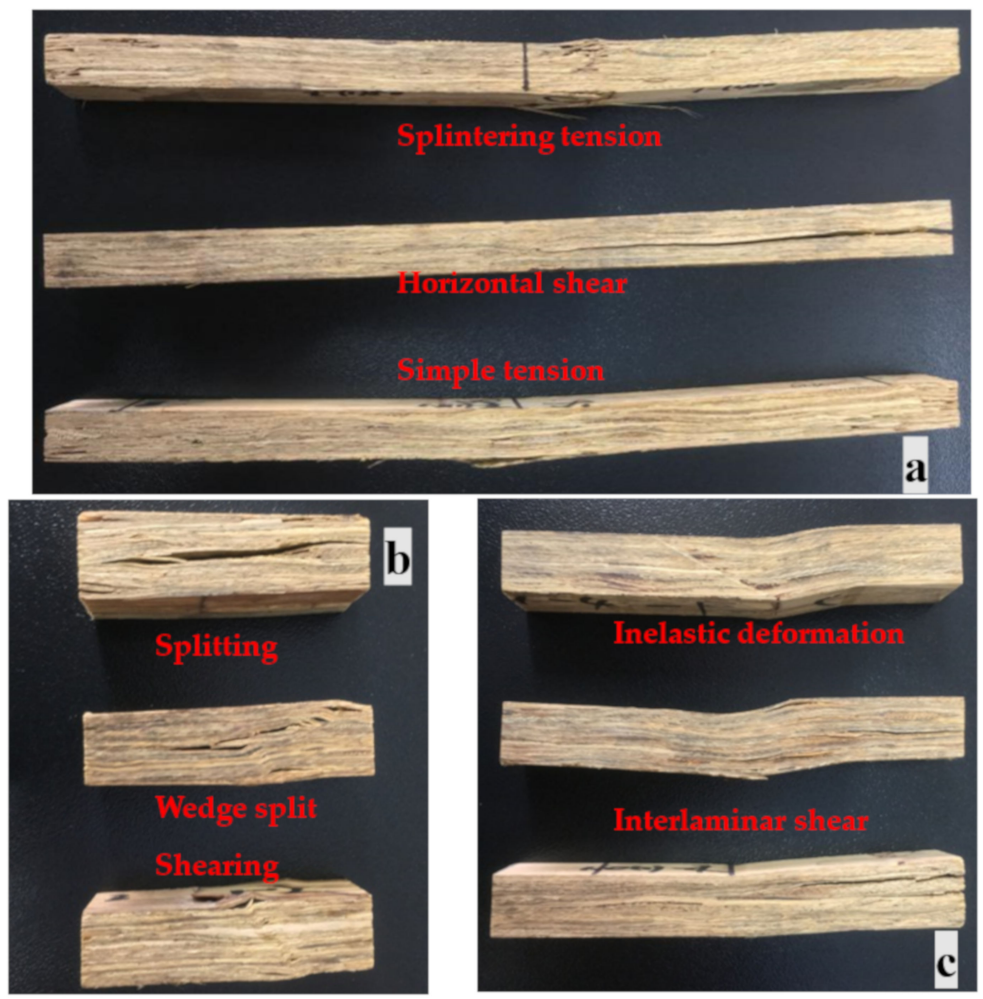

Figure 8. Typical failure modes of BOSL: (a) flexural failure; (b) compression failure; (c) shear failures.

\subsection{Comparison of Mechanical Properties}

Table 1 compares the results from different experimental studies on wood or bamboo-based composites. The MOR and MOE of BOSL with density $0.78 \mathrm{~g} / \mathrm{cm}^{3}$ in this study were $124.42 \mathrm{MPa}$ and 15,455 $\mathrm{MPa}$, respectively, which are 1.67 and 1.43 times those of OSL using urea-formaldehyde (UF) resin [37]. This may be due to the excellent properties of raw bamboo and PF resin. In addition, the flexural properties of BOSL in this study were superior to the results of Malanit et al. [19], which were closely related to resin content. BOSL produced from diphenylmethane diisocyanate $(10 \%)$ had less adhesive spread compared to the present research. Compared with LBL [38], the density, MOR and MOE of BOSL was higher, but the shear and compressive strength were lower. Compared to bamboo scrimber with density of above $1.0 \mathrm{~g} / \mathrm{cm}^{3}$, both bamboo scrimber and BOSL have high strength, but BOSL has the advantage of high-level automation over bamboo scrimber. As shown in Figure 9 , the performance of BOSL can be compared with, or is surpassed by, wood or bamboo products. With its advantages of high material utilization, excellent mechanical strength and scale production, BOSL would have emerged as highly applicable in the future.

Table 1. The mechanical properties comparison of wood or bamboo-based composites and present results.

\begin{tabular}{|c|c|c|c|c|c|c|}
\hline Material & $\begin{array}{c}\text { Adhesive Type } \\
\text { and Amount }\end{array}$ & $\begin{array}{l}\text { Density } \\
\left(\mathrm{g} / \mathrm{cm}^{3}\right)\end{array}$ & $\begin{array}{l}\text { MOR } \\
\text { (MPa) }\end{array}$ & $\begin{array}{l}\text { MOE } \\
\text { (MPa) }\end{array}$ & $\begin{array}{l}\text { Shear Strength } \\
\text { (MPa) }\end{array}$ & $\begin{array}{l}\text { Compression } \\
\text { Strength (MPa) }\end{array}$ \\
\hline \multirow{2}{*}{ BOSL $^{a}$} & \multirow{2}{*}{ PF $15 \%$} & 0.78 & 124.42 & 15,455 & 9.88 & 65.02 \\
\hline & & 1.22 & 157.22 & 20,050 & 16.9 & 106.71 \\
\hline $\mathrm{BOSL}^{\mathrm{b}}$ & pMDI 10\% & 0.76 & 62.5 & 10,497 & & \\
\hline OSL $^{c}$ & UF $10 \%$ & 0.80 & 74.31 & 10,817 & 12.67 & \\
\hline \multirow{2}{*}{$\begin{array}{c}\text { Bamboo scrimber } \\
\text { LBL }^{\mathrm{d}}\end{array}$} & PF $15-17 \%$ & 1.22 & 166.5 & 18,650 & 17.00 & 115.7 \\
\hline & & 0.69 & 80 & 12,000 & 16 & 77 \\
\hline
\end{tabular}

Note: ${ }^{a}=$ Present study, ${ }^{b}=$ Malanit et al. [19], ${ }^{c}=$ Bayatkashkoli et al. [38], ${ }^{\mathrm{d}}=$ Anuj et al. [35], ${ }^{\mathrm{e}}=$ Sharma et al. [38]. 


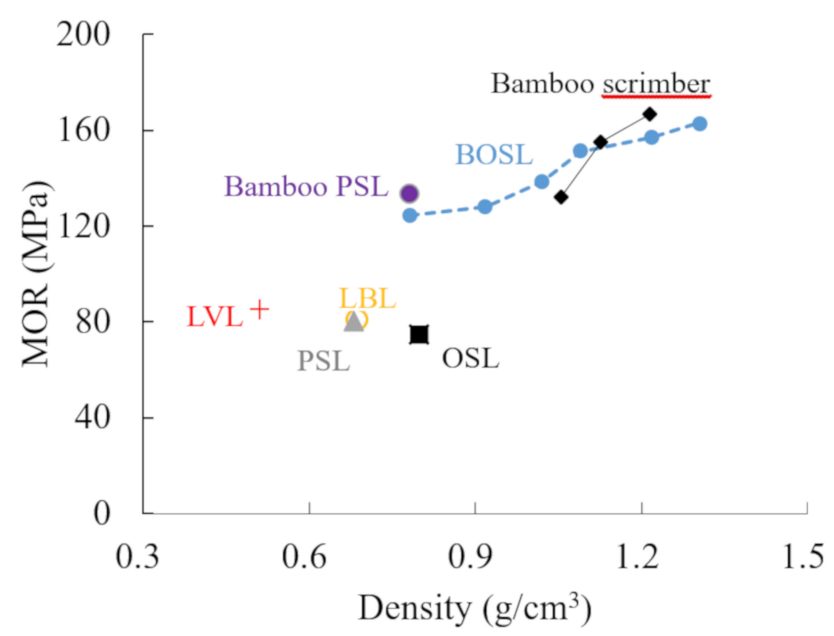

Figure 9. MOR comparison of BOSL with wood and other bamboo structural materials. MOR data of Parallel strand lumber (PSL), the data of bamboo-based PSL and Laminated veneer lumber (LVL) were from Anuj et al. [35] and Sharma et al. [37].

\section{Conclusions}

The current research investigated the influence of board density on the physical and mechanical properties of BOSL. The mechanisms of improved physical and mechanical properties of BOSL with the increase of density were also studied.

(1) The results revealed that MOR, MOE, compressive strength and shear strength of BOSL, with density of $0.7-1.3 \mathrm{~g} / \mathrm{cm}^{3}$, ranged from 124.42 to $163.2 \mathrm{MPa}, 15,455$ to $21,849 \mathrm{MPa}, 65.02$ to $111.63 \mathrm{MPa}$ and 9.88 to $18.35 \mathrm{MPa}$, respectively. The range of TS value was $4.39-10.61 \%$. The properties of BOSL significantly varied with its density, and it can be designed by controlling the density.

(2) The performance of BOSL can be comparable to or surpass that of wood or bamboo products. In addition, it has the advantages of high utilization rate and high degree of automation, so it will be highly desirable in different fields.

(3) The good water-resistance of BOSL with high density was primarily due to the enhanced gluing interface, and the reduced porosity and pore geometry. The high strength of BOSL with high density was primarily due to the increased volume fraction of elementary fibers, the reduced porosity, and the enhanced gluing interface.

It was one of the shortcomings of this study that samples were limited, and it will be necessary to increase the sufficient number of tests in order to permit further statistical treatment of the test data. Moreover, the research concerning the influence of resin content, strand dimension and biological characteristics of bamboo on the properties of BOSL will also be meaningful in the following works.

Author Contributions: Conceptualization, Y.S. and W.Y.; methodology, Y.S.; validation, Y.Z.; formal analysis, Y.H.; investigation, Y.H.; resources, W.Y.; data curation, W.Y.; writing-Original draft preparation, Y.S.; writing一Review and editing, Y.S.; visualization, Y.H.; supervision, Y.H.; project administration, X.W.; funding acquisition, W.Y. All authors have read and agreed to the published version of the manuscript.

Funding: This work was funded by the Special Funds for the National Key Research \& Development Program of China (2016YFD060090404).

Conflicts of Interest: The authors declare no competing financial interest.

\section{References}

1. Li, Z.; Chen, C.; Mi, R.; Gan, W.; Dai, J.; Jiao, M.; Xie, H.; Yao, Y.; Xiao, S.; Hu, L. A Strong, Tough, and Scalable Structural Material from Fast-Growing Bamboo. Adv. Mater. 2020, 32, 1-8. [CrossRef] [PubMed]

2. Chaowana, P. Bamboo: An Alternative Raw Material for Wood and Wood-Based Composites. J. Mater. Sci. Res. 2013, 2. [CrossRef] 
3. Dixon, P.G.; Gibson, L.J. The structure and mechanics of Moso bamboo material. J. R. Soc. Interface 2014, 11, 20140321. [CrossRef] [PubMed]

4. Yu, Y.; Zhu, R.; Wu, B.; Hu, Y.; Yu, W. Fabrication, material properties, and application of bamboo scrimber. Wood Sci. Technol. 2014, 49, 83-98. [CrossRef]

5. Shangguan, W.; Zhong, Y.; Xing, X.; Zhao, R.; Ren, H. 2D Model of Strength Parameters for Bamboo Scrimber. Bioresources 2014, 9. [CrossRef]

6. Li, H.-T.; Su, J.-W.; Zhang, Q.-S.; Deeks, A.; Hui, D. Mechanical performance of laminated bamboo column under axial compression. Compos. Part B Eng. 2015, 79, 374-382. [CrossRef]

7. Feng, M.Z. Research on the Impact of Physical Mechanical Properties of Structure Strip Plybamboo Condition on Hot-Pressing. Ph.D. Thesis, Beijing Forestry University, Beijing, China, 2013.

8. Verma, C.; Chariar, V. Development of layered laminate bamboo composite and their mechanical properties. Compos. Part B Eng. 2012, 43, 1063-1069. [CrossRef]

9. Febrianto, F.; Hidayat, W.; Bakar, E.S.; Kwon, G.-J.; Kwon, J.-H.; Hong, S.-I.; Kim, N.-H. Properties of oriented strand board made from Betung bamboo (Dendrocalamus asper (Schultes.f) Backer ex Heyne). Wood Sci. Technol. 2010, 46, 53-62. [CrossRef]

10. Semple, K.E.; Zhang, P.K.; Smith, G.D. Hybrid oriented strand boards made from Moso bamboo (Phyllostachys pubescens Mazel) and Aspen (Populus tremuloides Michx.): Species-separated three-layer boards. Eur. J. Wood Wood Prod. 2015, 73, 527-536. [CrossRef]

11. Wang, G.; Jiang, Z.H.; Chen, F.M.; Cheng, H.T.; Sun, F.B. Manufacture situation and problem analysis on large size bamboo engineering material in China. China For. Prod. Ind. 2014, 41, 48-49.

12. Huang, Y.; Ji, Y.; Yu, W. Development of bamboo scrimber: A literature review. J. Wood Sci. 2019, 65, 25. [CrossRef]

13. Mirski, R.; Derkowski, A.; Dziurka, D. Influence of strand size, board density, and adhesive type on characteristics of oriented strand lumber boards manufactured from pine strands. Bioresources 2019, 14, 6686-6696.

14. Bliem, P.; Frömel-Frybort, S.; Van Herwijnen, H.W.G.; Pinkl, S.; Krenke, T.; Mauritz, R.; Konnerth, J.; Van Herwijnen, H.W.G. Engineering of material properties by adhesive selection at the example of a novel structural wood material. J. Adhes. 2019, 96, 144-164. [CrossRef]

15. Malanit, P. The Suitability of Dendrocalamus asper Backer for Oriented Strand Lumber. Ph.D. Thesis, Informatics and Natural Sciences University of Hamburg, Hamburg, Germany, 2009.

16. Ferraz, J.M.; Del Menezzi, C.H.S.; Teixeira, D.E.; Okino, E.Y.A.; Souza, F.; Bravim, A.G. Properties of laminated strand panels used as an alternative to solid wood. Cerne 2009, 15, 67-74.

17. Taghiyari, H.R.; Maleki, S.; Hassani, V. Effects of Nano-Silane on the Physical and Mechanical Properties of Oriented Strand Lumber (OSL). Bois For. Trop. 2017, 330, 49. [CrossRef]

18. Yu, Y.; Huang, X.; Yu, W. A novel process to improve yield and mechanical performance of bamboo fiber reinforced composite via mechanical treatments. Compos. Part B Eng. 2014, 56, 48-53. [CrossRef]

19. Malanit, P.; Barbu, M.C.; Frühwald, A. Physical and mechanical properties of oriented strand lumber made from an Asian bamboo (Dendrocalamus asper Backer). Eur. J. Wood Wood Prod. 2010, 69, 27-36. [CrossRef]

20. Sumardi, I.; Suzuki, S.; Rahmawati, N. Effect of Board Type on Some Properties of Bamboo Strandboard. J. Math. Fundam. Sci. 2015, 47, 51-59. [CrossRef]

21. Semple, K.E.; Zhang, P.K.; Smola, M.; Smith, G.D. Hybrid Oriented Strand Boards made from Moso bamboo (Phyllostachys pubescens Mazel) and Aspen (Populus tremuloides Michx.): Uniformly mixed single layer uni-directional boards. Eur. J. Wood Wood Prod. 2015, 73, 515-525. [CrossRef]

22. Zhong, Y.; Wu, G.; Ren, H.; Jiang, Z. Bending properties evaluation of newly designed reinforced bamboo scrimber composite beams. Constr. Build. Mater. 2017, 143, 61-70. [CrossRef]

23. Peng, L.M.; Wang, D.; Fu, F.; Song, B.Q. Analysis of wood pore characteristics with mercury intrusion porosimetry and X-ray micro-computed tomography. Wood Res. 2015, 60, 857-864.

24. Ding, W.-D.; Koubaa, A.; Chaala, A.; Belem, T.; Krause, C. Relationship between wood porosity, wood density and methyl methacrylate impregnation rate. Wood Mater. Sci. Eng. 2008, 3, 62-70. [CrossRef]

25. Yu, Y.L. Manufacturing Technology and Mechanism of High Performance Bamboo-Based Fiber Composites. Ph.D. Thesis, Chinese Academy of Forestry, Beijing, China, 2014.

26. Lian, C.P.; Liu, R.; Zhang, S.Q. Research Progress on Anatomical Structure of Bamboo Vascular Bundles. China For. Prod. Ind. 2018, 9, 8-12. 
27. Liu, X.E.; Liu, Z.; Wang, Y.H. Investigation on main anatomical characteristics of Dendrocalamus giganteus. J. Anhui Agric. Univ. 2012, 39, 890-893.

28. Wang, Y.; Zhan, H.; Ding, Y.; Lin, S. Variability of Anatomical and Chemical Properties with Age and Height in Dendrocalamus brandisii. Bioresources 2015, 11, 1202-1213. [CrossRef]

29. Liu, R. Characteristics of Pits in Bamboo (Phyllostachys edulis) Revealed by Resin Casting. Ph.D. Thesis, Chinese Academy of Forestry, Beijing, China, 2017.

30. Gavrilovic-Grmusa, I.; Dunky, M.; Djiporovic-Momcilovic, M.; Popović, M. Influence of Pressure on the Radial and Tangential Penetration of Adhesive Resin into Poplar Wood and on the Shear Strength of Adhesive Joints. Bioresources 2016, 11. [CrossRef]

31. Frederick, A.K.; Jong, N.L. Adhesive penetration in wood-A review. Wood Fiber Sci. 2007, 39, $205-220$.

32. Yu, Y.; Liu, R.; Huang, Y.; Meng, F.; Yu, W. Preparation, physical, mechanical, and interfacial morphological properties of engineered bamboo scrimber. Constr. Build. Mater. 2017, 157, 1032-1039. [CrossRef]

33. Li, B.; Zhao, M.Y.; Wang, X.P. Influence of irregular-void on transverse tensile mechanical properties of composites. Acta Mater. Compos. Sin. 2019, 36, 94-99.

34. Krause, J.Q.; Silva, F.D.A.; Ghavami, K.; Gomes, O.; Filho, R.D.T. On the influence of Dendrocalamus giganteus bamboo microstructure on its mechanical behavior. Constr. Build. Mater. 2016, 127, 199-209. [CrossRef]

35. Kumar, A.; Vlach, T.; Laiblova, L.; Hrouda, M.; Kasal, B.; Tywoniak, J.; Hajek, P. Engineered bamboo scrimber: Influence of density on the mechanical and water absorption properties. Constr. Build. Mater. 2016, 127, 815-827. [CrossRef]

36. Li, Z.; He, M.; Tao, D.; Li, M. Experimental buckling performance of scrimber composite columns under axial compression. Compos. Part B Eng. 2016, 86, 203-213. [CrossRef]

37. Bayatkashkoli, A.; Faegh, M. Evaluation of mechanical properties of laminated strand lumber and oriented strand lumber made from Poplar wood (Populus deltoides) and Paulownia (Paulownia fortunei) with urea formaldehyde adhesive containing nanoclay. Int. Wood Prod. J. 2014, 5, 192-195. [CrossRef]

38. Sharma, B.; Gatóo, A.; Bock, M.; Ramage, M. Engineered bamboo for structural applications. Constr. Build. Mater. 2015, 81, 66-73. [CrossRef] 